Note

\section{Evaluation of Local Dissolution Rates and Wetting Behaviors of Solid Alumina in Liquid Slag with the Marangoni Number}

\section{Yoshiyuki UESHIMA*}

Nippon Steel \& Sumitomo Metal Corporation, 20-1 Shintomi, Futtsu, Chiba Prefecture, 293-8511 Japan.

(Received on February 27, 2016; accepted on April 26, 2016)

Dissolution experiments of solid alumina in four kinds of liquid slags corresponding to cover-slags, LF-slag and fluorspar were conducted at $1600^{\circ} \mathrm{C}$ under an atmosphere of dry air. The local dissolution rates of alumina and the flow velocities and wetting behaviors around the meniscus line were analyzed with the Marangoni number.

KEY WORDS: dissolution; wetting; alumina; slag; the Marangoni effect.

\section{Introduction}

Accelerating slagging, improving inclusion removal, and prolonging refractory lifetime are still important subjects for steelmaking engineers in order to attain high-grade steel production at higher efficiencies. Basically, these phenomena can be considerably affected by the liquid-solid interfacial properties of oxides, as well as the bulk properties of oxides. From this viewpoint, dissolution experiments of solid alumina in liquid slags were conducted at $1600^{\circ} \mathrm{C}$. The local dissolution rates of alumina and the flow velocities and wetting behaviors around the meniscus line were analyzed with the Marangoni number.

\section{Experiment}

A schematic drawing of the experimental set-up is shown in Fig. 1(a). Cold-pressed disc-shaped slag powder samples $(40 \mathrm{~g}, 38 \mathrm{mmD} \times 20 \mathrm{mmH})$ were placed in high-purity dense polycrystalline alumina crucibles $\left(99.6 \% \mathrm{Al}_{2} \mathrm{O}_{3}, 50\right.$ $\mathrm{mmOD} \times 42 \mathrm{mmID} \times 150 \mathrm{mmH}$ ). The chemical compositions of the slag samples are shown in Table 1, which correspond to two kinds of cover-slags, LF-slag and metallurgical fluorspar for steelmaking plants, respectively. The samples were melted at $1600^{\circ} \mathrm{C}$ for $15 \mathrm{~min}$ or $3 \mathrm{~h}$ under an atmosphere of dry air, and then they were air-cooled following removal from the lower part of the furnace. After breaking the alumina crucibles containing the slags with a hammer, vertical cross sections of the samples were observed. Then, the characteristic values of $\theta, \mathrm{h}, \delta$, and $\delta$ ' as shown in Fig.

\footnotetext{
* Corresponding author: E-mail: ueshima.br4.yoshiyuki@jp.nssmc.com DOI: http://dx.doi.org/10.2355/isijinternational.ISIJINT-2016-118
}

1(b) were measured, where $\theta$ is the contact angle, $\mathrm{h}$ is the wetting height, $\delta$ is the maximum dissolved loss of the vertical wall of alumina at the meniscus lines, and $\delta$ ' is the average loss of the bottom wall.

\section{Results}

Optical images of the vertical cross sections of the slag samples after the experiments are shown in Fig. 2, and the (a)

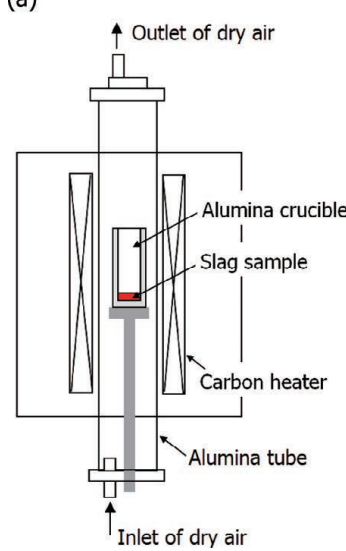

(b)

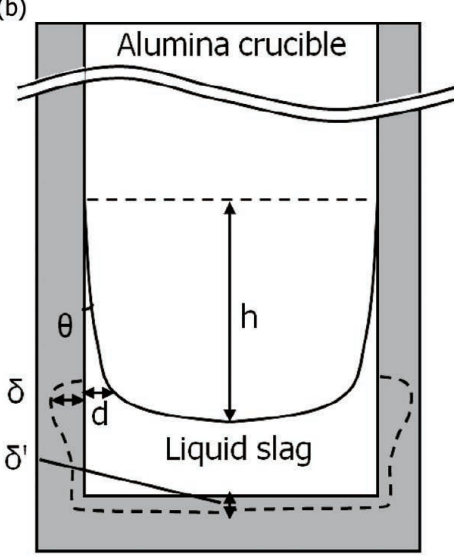

Fig. 1. Schematic drawings of (a) the experimental set-up and (b) wetting behavior of liquid slag in the alumina crucible. The dashed lines indicate the locations of the alumina-slag boundaries after the dissolution experiments.

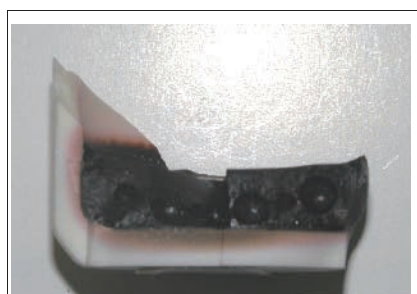

(a) Slag 1 $\underline{10 \mathrm{~mm}}$

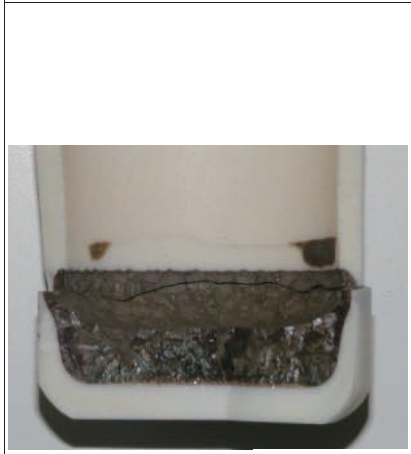

(c) Slag 3

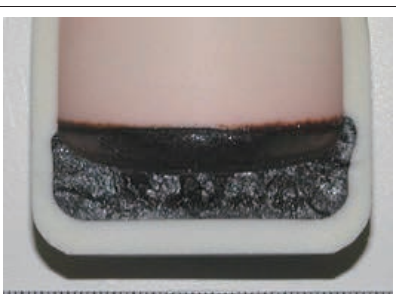

(b) Slag 2 $10 \mathrm{~mm}$

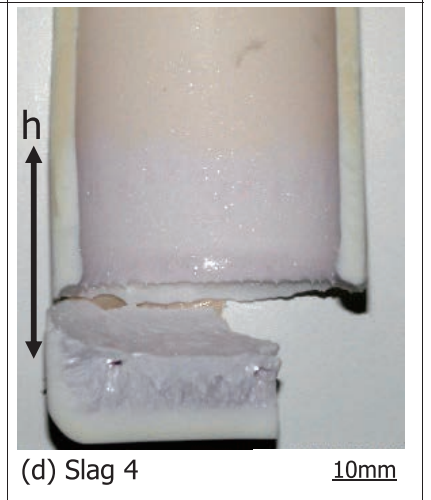

Fig. 2. Appearance of the liquid slag inside the alumina crucibles after the dissolution experiments. The holding time at $1600^{\circ} \mathrm{C}$ for Slags $1-3$ was $3 \mathrm{~h}$ and $15 \mathrm{~min}$ for Slag 4 .

Table 1. Chemical composition of the slag (unit: $\operatorname{mass} \%$ ).

\begin{tabular}{cccccccc}
\hline Slag No. & $\mathrm{CaO}$ & $\mathrm{SiO}_{2}$ & $\mathrm{MgO}$ & $\mathrm{Al}_{2} \mathrm{O}_{3}$ & $\mathrm{FeO}$ & $\mathrm{MnO}$ & $\mathrm{CaF}_{2}$ \\
\hline 1 & 16 & 14 & 7 & 44 & 7 & 12 & - \\
2 & 33 & 7 & 4 & 47 & 3 & 6 & - \\
3 & 50 & - & - & 50 & - & - & - \\
4 & - & 10 & - & - & - & - & 90
\end{tabular}


Table 2. Experimental results (upper part) and related physico-chemical properties of the slag samples (lower part).

\begin{tabular}{cccccc}
\hline \multirow{2}{*}{ Symbol } & Unit & \multicolumn{4}{c}{ Slag No. } \\
\cline { 3 - 6 } & & 1 & 2 & 3 & 4 \\
\hline$\theta$ & $\mathrm{mm}$ & 3 & 27 & 7 & 2 \\
$\mathrm{~h}$ & $\mathrm{~mm}$ & 0.1 & 8 & 14 & 35 \\
$\delta$ & $\mathrm{mm}$ & 0.03 & 0.07 & 0.03 & 4.0 \\
$\delta$ & $\mathrm{s}$ & 10800 & 10800 & 10800 & 0.30 \\
$\mathrm{t}$ & $\mathrm{m} / \mathrm{s}$ & $9.3 \cdot 10^{-9}$ & $1.4 \cdot 10^{-7}$ & $3.0 \cdot 10^{-7}$ & $4.4 \cdot 10^{-6}$ \\
$\mathrm{v}$ & $\mathrm{m} / \mathrm{s}$ & $2.8 \cdot 10^{-9}$ & $6.5 \cdot 10^{-9}$ & $3.1 \cdot 10^{-9}$ & $3.3 \cdot 10^{-7}$ \\
$\mathrm{v}$ & 1597 & 1451 & 1400 & 1390 \\
$\mathrm{~T}_{\mathrm{L}}$ & ${ }^{\circ} \mathrm{C}$ & 46 & 65 & 68 & 50 \\
$\left(\% \mathrm{Al}_{2} \mathrm{O}_{3}\right)^{\mathrm{s}}$ & $\mathrm{mass} \%$ & 44 & 47 & 50 & 0 \\
$\left(\% \mathrm{Al}_{2} \mathrm{O}_{3}\right)^{\mathrm{b}}$ & $\mathrm{mass} \%$ & 2 & 18 & 18 & 50 \\
$\Delta\left(\% \mathrm{Al}_{2} \mathrm{O}_{3}\right)$ & $\mathrm{mass} \%$ & 0.24 & 0.14 & 0.068 & 0.013 \\
$\eta$ & $\mathrm{Pa} \cdot \mathrm{s}$ & 2980 & 2860 & 2730 & 2550 \\
$\rho$ & $\mathrm{kg} / \mathrm{m}^{3}$ & $8.05 \cdot 10^{-5}$ & $5.42 \cdot 10^{-5}$ & $2.47 \cdot 10^{-5}$ & $5.10 \cdot 10^{-6}$ \\
$\nu$ & $\mathrm{m} / \mathrm{s}$ & 570 & 590 & 620 & 270 \\
$\sigma$ & $\mathrm{mN} / \mathrm{m}$ & +0.9 & +0.6 & +0.3 & +2.2 \\
$\partial \sigma / \partial\left(\% \mathrm{Al}_{2} \mathrm{O}_{3}\right)$ & $\mathrm{mN} / \mathrm{m} / \mathrm{mass} \%$ & $4.4 \cdot 10^{4}$ & $5.0 \cdot 10^{5}$ & $4.6 \cdot 10^{5}$ & $5.3 \cdot 10^{7}$ \\
$\mathrm{Ma}^{2}$ & - & & &
\end{tabular}

measured values and related physico-chemical properties are shown in Table 2, where $\mathrm{v}(=\delta / \mathrm{t})$ and $\mathrm{v}^{\prime}\left(=\delta^{\prime} / \mathrm{t}\right)$ are the time-averaged dissolution rates at the meniscus lines and the bottoms, respectively. The phase diagram data of the liquidus temperatures of slags $\mathrm{T}_{\mathrm{L}}$ and the saturated concentration of alumina in the slags $\left(\% \mathrm{Al}_{2} \mathrm{O}_{3}\right)^{\mathrm{s}}$ were quoted from SLAG ATLAS ${ }^{1)}$ or calculated based on an in-house database, ${ }^{2)}$ and the other properties were evaluated using the software SLAGS 1.07. ${ }^{3)}$ From this data, the values of Ma were calculated form Eq. (1) for Slags 1-4.

$$
\mathrm{Ma} \equiv\left(\partial \sigma / \partial\left(\% \mathrm{Al}_{2} \mathrm{O}_{3}\right)\right) \cdot \Delta\left(\% \mathrm{Al}_{2} \mathrm{O}_{3}\right) \cdot \mathrm{d} /(\mathrm{D} \cdot \eta)
$$

where $\sigma$ is the surface tension of the slag, $\Delta\left(\% \mathrm{Al}_{2} \mathrm{O}_{3}\right)$ is the difference between the saturated concentration $\left(\% \mathrm{Al}_{2} \mathrm{O}_{3}\right)^{\mathrm{s}}$ and the bulk concentration $\left(\% \mathrm{Al}_{2} \mathrm{O}_{3}\right)^{\mathrm{b}}$, $\mathrm{d}$ is the wetting slag film thickness of $1 \mathrm{~mm}$ as shown in Fig. 1(b), D is the selfdiffusion coefficient of aluminum of $1.6 \times 10^{-10} \mathrm{~m}^{2} / \mathrm{s},{ }^{4)}$ and $\eta$ is the slag viscosity.

Correlation between the dissolution rate of alumina in the slag and the wetting height of the slag is shown in Fig. 3. The solid and the dashed regression lines show $\mathrm{v}$ and $\mathrm{v}$, respectively. A rather good correlation between $\mathrm{v}$ and $\mathrm{h}$ was found.

\section{Discussion}

\subsection{Contact Angles, Wetting Heights, Flow Velocities, and Local Dissolution Rates Evaluated with the Marangoni Number}

We analyzed the four characteristic values of the contact angle $\theta$, wetting height $\mathrm{h}$, flow velocity $\mathrm{u}$, and local dissolution rate $\mathrm{v}$ with the Marangoni number. First, it was necessary to estimate the value of $u$ from that of $v$ on the assumption of a one-dimensional steady-state mass transfer of alumina in the liquid slag and local equilibrium at the alumina-slag interface. At the meniscus lines, the flux of alumina $\mathrm{J}_{\mathrm{Al}_{2} \mathrm{O}_{3}}$ can be written as Eq. (2), where $\mathrm{M}_{\mathrm{Al}_{2} \mathrm{O}_{3}}$ is the molar weight of alumina, and $\mathrm{m}_{\mathrm{Al} 2 \mathrm{O} 3}$ is the transfer coef-

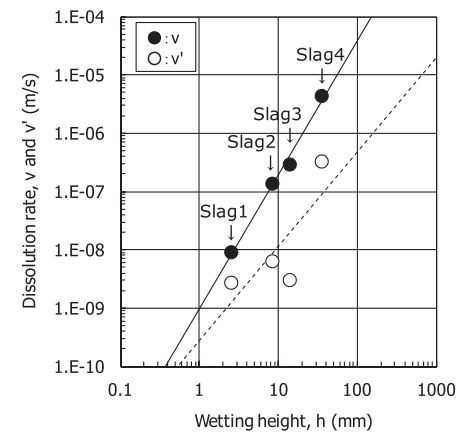

Fig. 3. Correlation between the dissolution rate of alumina in the slag and the wetting height of the slag. Symbols of $\mathrm{v}(=\delta / \mathrm{t})$ and $\mathrm{v}^{\prime}\left(=\delta^{\prime} / \mathrm{t}\right)$ mean the time-averaged dissolution rates at the meniscus lines and the bottoms, respectively, where $\delta$ is the maximum dissolved loss of the vertical wall of alumina at the meniscus lines, and $\delta$ ' is the average loss of the bottom wall.

ficient of alumina in the slag.

$$
\begin{aligned}
\mathrm{J}_{\mathrm{Al}_{2} \mathrm{O}_{3}} & =\mathrm{v} \cdot\left(100-\left(\% \mathrm{Al}_{2} \mathrm{O}_{3}\right)^{\mathrm{s}}\right) / 100 \cdot \rho_{\mathrm{Al}_{2} \mathrm{O}_{3}} / \mathrm{M}_{\mathrm{Al}_{2} \mathrm{O}_{3}} \\
& =\mathrm{m}_{\mathrm{Al}_{2} \mathrm{O}_{3}} \cdot \Delta\left(\% \mathrm{Al}_{2} \mathrm{O}_{3}\right) / 100 \cdot \rho_{\text {slag }} / \mathrm{M}_{\mathrm{Al}_{2} \mathrm{O}_{3}}
\end{aligned}
$$

When the flow of the liquid slag at the meniscus lines is assumed to be a planar flow on a flat plate, the Sherwood number Sh can be written as Eq. (3).

$$
\mathrm{Sh}=\mathrm{m}_{\mathrm{Al}} \cdot \mathrm{L} / \mathrm{D}=0.664 \cdot\left(\mathrm{u}^{1 / 2} \cdot \mathrm{L}^{1 / 2}\right) /\left(v^{1 / 6} \cdot \mathrm{D}^{1 / 3}\right) \ldots(3
$$

where $\mathrm{L}$ is the slag depth of $10 \mathrm{~mm}$ and $v$ is the kinetic viscosity of the slag. Using the relationship of $\mathrm{m}_{\mathrm{Al}}=2 \cdot \mathrm{m}_{\mathrm{Al}_{2} \mathrm{O}_{3}}$, where $\mathrm{m}_{\mathrm{Al}}$ is the transfer coefficient of aluminum in the slag, and Eqs. (2) and (3), it is possible to obtain Eq. (4).

$$
\begin{aligned}
& \mathrm{u}=4 \cdot \mathrm{v}^{2} \cdot\left(\left(100-\left(\% \mathrm{Al}_{2} \mathrm{O}_{3}\right)^{s}\right) /\right. \\
& \left(\Delta\left(\% \mathrm{Al}_{2} \mathrm{O}_{3}\right) \cdot\left(\rho_{\mathrm{Al}_{2} \mathrm{O}_{3}} / \rho_{\text {slag }}\right)\right)^{2} /\left(0.441 \cdot \mathrm{D}^{4 / 3}\right) \cdot\left(\mathrm{L} \cdot v^{1 / 3}\right)
\end{aligned}
$$

After obtaining the desired characteristic values of $\theta, \mathrm{h}$, $\mathrm{u}$, and $\mathrm{v}$, their correlations with the values of Ma are shown 


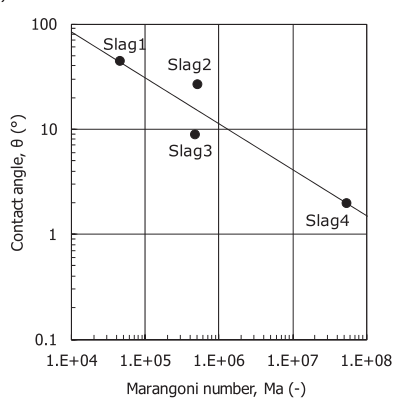

(c)

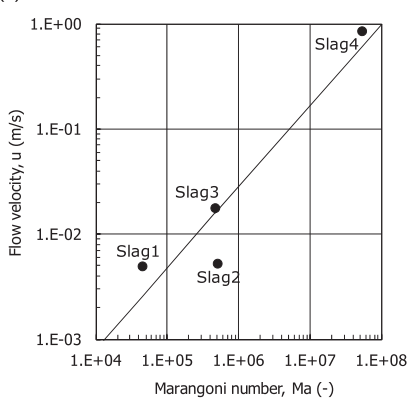

(b)

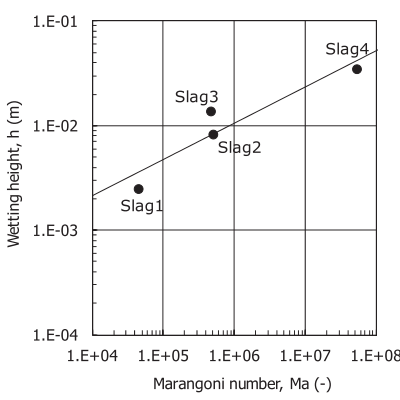

(d)

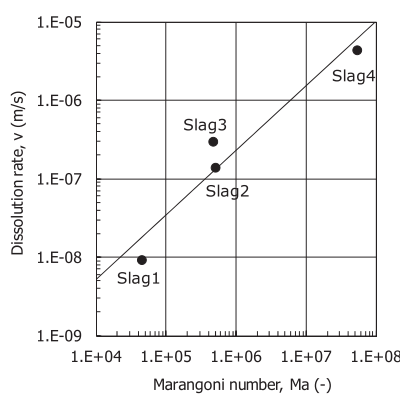

Fig. 4. Contact angles, wetting heights, flow velocities and dissolution rates as a function of the Marangoni number.

in Fig. 4 with linear regression lines formulated as Eqs. (5)(8). The slag having a larger value of the Marangoni number Ma shows a smaller contact angle $\theta$, a larger wetting height $\mathrm{h}$, a larger flow velocity $\mathrm{u}$ and a larger dissolution rate $\mathrm{v}$. Each value of Ma for Slags 1-4 is much higher than unity, and Slag 4 (fluorspar) in particular had the highest value of $5 \times 10^{7}$. Using Eqs. (5)-(8), characteristic values for lime and silica in the liquid fluorspar were estimated from the values of $\mathrm{Ma}$, and it was found that rather high wettability and dissolution rates for lime and silica also occurred at the same extent as alumina. Consequently, it is concluded that the empirically well-known effect of fluorspar as a slagging accelerator comes not only from a decrease in liquidus temperatures and viscosities of the refining slags after completely mixing, but also from a spontaneous increase in the reaction areas and slag flow velocities due to the strong Marangoni effect appearing at the three-phase boundary between solid refining agents, liquid fluorspar, and air during the early stages of slagging.

$$
\begin{aligned}
& \theta=5.0 \times 10^{3} \cdot \mathrm{Ma}^{-0.44} \\
& \mathrm{~h}=8.7 \times 10^{-5} \cdot \mathrm{Ma}^{0.35} \\
& \mathrm{u}=6.7 \times 10^{-7} \cdot \mathrm{Ma}^{0.77} \\
& \mathrm{v}=2.6 \times 10^{-12} \cdot \mathrm{Ma}^{0.82}
\end{aligned}
$$

\subsection{Correlation between the Contact Angles and the Local Dissolution Rates and Alumina Flux}

The correlations between $\theta$ and the values of $\mathrm{V}$ and $\mathrm{J}_{\mathrm{Al}_{2} \mathrm{O}_{3}}$ are shown in Fig. 5 with previously reported data. ${ }^{5-7)}$ The solid lines in this figure are Eqs. (9) and (10), which were obtained by combining Eqs. (2), (5), and (8). The slag with a larger dissolution rate $\mathrm{v}$ and a larger alumina flux $\mathrm{J}_{\mathrm{Al}_{2} \mathrm{O}_{3}}$
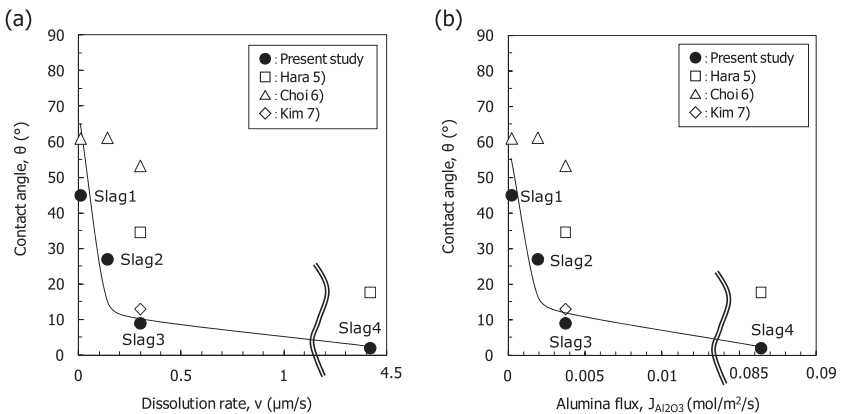

Fig. 5. Correlation between the contact angle and the dissolution rate and alumina flux.

shows a smaller contact angle $\theta$, which indicates the correlation between dynamic wettablilty and reactivity of these slags at the meniscus lines under the atmosphere of dry air.

$$
\begin{gathered}
\theta=3.5 \times 10^{-3} \cdot \mathrm{v}^{-0.53} \cdots \\
\theta=6.3 \times 10^{-1} \cdot \mathrm{J}_{\mathrm{Al}_{2} \mathrm{O}_{3}}{ }^{-0.52}
\end{gathered}
$$

It is interesting to note that the negative correlation between $\theta$ and the values of $\mathrm{v}$ and $\mathrm{J}_{\mathrm{Al}_{2} \mathrm{O}_{3}}$ is similar to the dynamic behaviors of declining contact angles and interfacial tensions between liquid slag and liquid iron during de-S, de-O, and de-P reactions, ${ }^{8-22)}$ and this is most likely attributable to the adsorption of surface active elements such as $\mathrm{S}$ and $\mathrm{O}$, and Marangoni flow induced by gradients in interfacial tensions due to some fluctuation in the reaction rates at the slag-metal interfaces. In the present study, phenomenological analysis was carried out with the Marangoni number, and further study is needed to clarify similarities from the viewpoint of microscopic kinetics.

\section{REFERENCES}

1) SLAG ATLAS, 2nd ed., ed. by VDEh, Verlag Stahleisen, Düsseldolf, (1995), 186.

2) W. Yamada and T. Matsumiya: Nippon Steel Tech. Rep., 342 (1991), 38

3) National Physical Laboratory: SLAGS 1.07, NPL, London, (1997).

4) The Iron and Steel Institute of Japan: Handbook of Iron and Steel 3rd ed., Vol. 2, ed. by ISIJ, Maruzen, Tokyo, (1979), 45.

5) K. Nakajima: Tetsu-to-Hagané, 80 (1994), 383. See Table 4.

6) J-Y. Choi and H-G. Lee: ISIJ Int., 43 (2003), 1348.

7) S-J. Kim, K. Lee and Y. Chung: Asia Steel Int. Conf. 2015, ISIJ, Tokyo, (2015), 408.

8) P. Kozakevitch, G. Urbain and M. Sage: Rev. Metall., 2 (1955), 161.

9) K. Mori and T. Fujimura: Tetsu-to-Hagané, 41 (1955), 495.

10) K. Ogino, T. Suetaki, K. Niioka and A. Adachi: Tetsu-to-Hagané, 53 (1967), 769.

11) H. Ooi, T. Nozaki and H. Yoshii: Tetsu-to-Hagané, 58 (1972), 830.

12) K. Ogino, S. Hara, A. Adachi and H. Kuwata: Tetsu-to-Hagané, 59 (1973), 28.

13) K. Ogino: Tetsu-to-Hagané, 61 (1975), 2118

14) P. V. Riboud and L. D. Lucas: Can. Metall. Q., 20 (1981), 199.

15) H. Gaye, L. D. Lucas, M. Olette and P. V. Riboud: Can. Metall. Q., 23 (1984), 179.

16) I. Jimbo, Y. Chung and A. W. Cramb: ISIJ Int., 36 (1996), supplement, S42.

17) Y. Chung, A. W. Cramb, J. Harman, A. Sharan and I. Jimbo: Iron Steelmaker, 24 (1997), No. 3, 77.

18) Y. Chung and A. W. Cramb: Philos. Trans. R. Soc. Lond. A, 356 (1998), 981 .

19) Y. Chung and A. W. Cramb: Met. Trans. B, 31B (2000), 957.

20) M. Nasu, K. C. Mills, B. J. Monaghan, A. Jakobsson and S. Seetharaman: Ironmaking Steelmaking, 26 (1999), 353.

21) J. Lee and K. Morita: ISIJ Int., 44 (2004), 235.

22) T. Yoshikawa, K. Motosugi, T. Tanaka and M. Ueda: Tetsu-toHagané, 97 (2011), 361. 